\title{
PRIM: a model case of collaborative governance Agusdin
}

\author{
Agusdin, Associate Professor, Faculty of Economics and Business, University of Mataram \\ Email:dragusdin@gmail.com; agusdin@unram.ac.id
}

\begin{abstract}
English)
That which looks like a road to Directorate General of Highways is a lifeline to citizens, a framework for development for regional government, and a source of livelihood in road construction. These four different perspective of stakeholders form the basis of innovative collaboration in the acclaimed Provincial Road Improvement Program (PRIM) in NTB. Quality of regional roads and road maintenance has vastly improved through the program, and its success lies in collaboration.

This paper presents the four perspectives of the collaboration and concludes with lessons learnt. Representatives of each will be present at the IAPA conference presentation.

(1) Local government of West Lombok will report how PRIM has resulted, in more productive investment in roads, and also how civil society engagement adds value and how managerial support improves regional government capacity. Local government will also indicate how the grant mechanism, hibah jalan, provides a valuable incentive to improve design and construction quality.

(2) A representative of the Forum Lalu Lintas dan Angkutan Jalan, will describe the social inclusion aspects of PRIM, and how the outcomes satisfy real community needs.

(3) A representative of the local engineering profession will demonstrate how PRIM enables them to be more professional and how it helps construction companies to gain a better business reputation.

(4) The Head of Bina Marga's subdirectorate for facilitating regional roads describes how observing the excellence of PRIM has led to plans to adopt PRIM practices nation-wide.
\end{abstract}

Keywords: collaborative governance; innovative collaboration; local government; road maintenance; NTB; PRIM.

\section{Introduction}

NTB Province has received extensive development assistance from the Provincial Road Improvement and Maintenance Program (PRIM) since 2011. First through the Indonesia Infrastructure Initiative (IndII) and then since mid-2017 through its successor, the Indonesia Australia Partnership for Infrastructure (KIAT). This development assistance began with the investigation and design of the PRIM program in 2011, which since 2013 has produced full-time direct assistance for the NTB province, which has since been extended to district level assistance in West Lombok District since 2016. This development assistance was implemented through the implementation of various strategies simultaneously, adjusted to each stage of the annual road maintenance cycle. The experience gained at the provincial and district levels is very significant in the form of annual repetition of technical assistance that strengthens the retention of knowledge transfer to the Office of Public Works and Spatial Planning Service (DPU PR). However, most of the transfer of knowledge was carried out through project consultants funded with grants from the Australian Department of Foreign Affairs and Trade (DFAT).

DPU PR recognizes the risk of knowledge retention by the province - and hence sustainable capacity development - with dependence on outside consultants and funding. Therefore, both the provincial and district governments have tried to expand the exposure of PRIM's operational procedures to all staff, even those involved in road maintenance activities not funded by PRIM. The aim of this farsighted decision is to help embed these practices as permanent institutional reforms which will then be initiated in the future road maintenance cycle. Thus, NTB gained a reputation as a new source of useful experience and transformational advice regarding road maintenance. The central government is aware of the positive results of PRIM in NTB. Therefore, the central government through Subdirectorate of Subnational Roads Technical Guidance (SBTJD) wants to help other provinces implement good experiences from PRIM. As the central government examines how this important element of the PRIM model can be replicated elsewhere in Indonesia, as a parallel step, SBTJD wants to maintain the 
intellectual property obtained by NTB and encourage its proper use by providing as much data and proven procedures as possible for other provinces.

Usually the public sector such as DPU PR or the private sector (profit or nonprofit entities) dealt independently in providing and serve most of the needs of society. When there was a need for both sectors to be involved, a range of methods was employed, from formal contracting for services, to independent philanthropy by the private sector, to supply the service. Governance is a broader concept than government and also includes the roles played by the community sector and the private sector in managing and planning countries, regions and cities. Collaborative Governance involves the government, community and private sectors communicating with each other and working together to achieve more than any one sector could achieve on its own.

Ansell and Gash (2008) said that the ultimate goal is to develop a contingency approach of collaboration that can highlight conditions under which collaborative governance will be more or less effective as an approach to policy making and public management. Collaborative governance covers both the informal and formal relationships in problem solving and decision-making. Conventional government policy processes can be embedded in wider policy processes by facilitating collaboration between the public, private and community sectors. Collaborative Governance requires three things, namely: support; leadership; and a forum. The support identifies the policy problem to be fixed. The leadership gathers the sectors into a forum. Then, the members of the forum collaborate to develop policies, solutions and answers. Ansell and Gash (2008) also stated that:

One form of collaborative governance is collaborative network - "This system is meant to accomplish more alignment among community needs, strategies of service agencies, priority outcomes, and resource allocation. It's also meant to accomplish building social capital; integration of human service delivery; and interconnected strategies for relationship building, learning processes, and measurement and modeling among the participants."

New collaborative approaches to governing and managing have developed in a range of fields, including: urban and regional planning; public administration and law; natural resource management; and environmental management. Collaborative governance has emerged as a response to the failures of government policy implementation and to the high cost and politicization of regulation and as an alternative to managerialism and adversarial approaches. The field of public administration has changed its focus from bureaucracy to that of collaboration in the context of the network society. Public administrators have blurred the lines between the people, the private sector and the government. Although bureaucracies still remain, public administrators have begun to recognize that more can potentially be achieved by collaboration and networking. Collaboration and partnerships are nothing new in the political realm, however the wider use of this leadership style has gained momentum in recent years.

Ansell and Gash (2008) define collaborative governance as follows:

"A governing arrangement where one or more public agencies directly engage non-state stakeholders in a collective decision-making process that is formal, consensus-oriented, and deliberative and that aims to make or implement public policy or manage public programs or assets".

This definition involves six criteria:: (1) the forum is initiated by public agencies; (2) participants in the forum include non-state actors; (3) participants engage in decision making and are not merely "consulted"; (4) the forum is formally organized; (5) the forum aims to make decisions by consensus; and (6) the focus of collaboration is on public policy or public management.

Emerson, Nabatchi and Balogh (2012) have also developed a definition as follows:

"The processes and structures of public policy decision making and management that engage people constructively across the boundaries of public agencies, levels of government, and/or the public, private and civic spheres in order to carry out a public purpose that could not otherwise be accomplished." 
This framework definition is a broader analytic concept and does not limit collaborative governance to state-initiated arrangements and to engagement between government and nongovernment sectors.

This paper discuss the four perspectives of the collaborative governance between stakeholders under PRIM assistance in NTB Province as follows:

- DPU PR Kabupaten Lombok Barat on how PRIM has resulted, in more productive investment in roads, and also how civil society engagement adds value and how managerial support improves regional government capacity. It will also indicate how the grant mechanism, hibah jalan, provides a valuable incentive to improve design and construction quality of road maintenance;

- The Forum Lalu Lintas dan Angkutan Jalan (FLAJJ) is about the gender and social inclusion aspects of PRIM, and how the outcomes satisfy real community needs;

- The local engineering profession is about how PRIM enables them to be more professional and how it helps construction companies to gain a better business reputation;

- The Head of Bina Marga's subdirectorate for facilitating regional roads is how observing the excellence of PRIM has led to plans to adopt PRIM practices nation-wide.

\section{Methodology}

Type of research is descriptive with data collected from the secondary and primary sources. Data were collected using documentation for secondary data and primary data were collected using indepth interview with the stakeholders: (1) DPU PR Kabupaten Lombok Barat on how PRIM has resulted, in more productive investment in roads, and also how civil society engagement adds value and how managerial support improves regional government capacity. It will also indicate how the grant mechanism, hibah jalan, provides a valuable incentive to improve design and construction quality of road maintenance; (2) The Forum Lalu Lintas dan Angkutan Jalan (FLAJJ) is about the gender and social inclusion aspects of PRIM, and how the outcomes satisfy real community needs; (3) The local engineering profession is about how PRIM enables them to be more professional and how it helps construction companies to gain a better business reputation; (4) The Head of Bina Marga's subdirectorate of Technical Guidance for facilitating regional roads is how observing the excellence of PRIM has led to plans to adopt PRIM practices nation-wide. Data were analysed qualitatively using Content Analysis and Cross-Tabulation.

\section{Discussion}

Abbott (2012) has reviewed metropolitan planning in South East Queensland (SEQ), Australia where collaborative governance arrangements, between State and local governments and the regional community, have evolved over a 20 -year period leading to positive outputs and outcomes.

The positive outputs and outcomes of collaborative governance and metropolitan planning in SEQ have been extensive and broad and extend well beyond statutory regional land use planning. These include: three endorsed non-statutory regional plans; two endorsed statutory regional plans; an infrastructure program linked to the State budget; regional sectoral plans for transport, water supply, natural resource management, etc.; new legislation and institutional arrangements for metropolitan governance; and capital works such as the SEQ busway network. The advantages of effective collaborative governance are that it enables a better and shared understanding of complex problems involving many stakeholders and allows these stakeholders to work together and agree on solutions. It can help policy makers identify and target problems and deliver action more effectively. Stakeholders that are involved in developing a solution are more inclined to accept directions given or decisions made. It can thus serve as a way to identify policy solutions that have greater traction in the community. However, the disadvantages of collaborative governance are that the process is time consuming, it may not reach agreement on solutions, and the relevant government agencies may not implement the agreed solutions. In a complex structure with many entities working together, individual roles can become unclear and confusing. Some individuals act largely in a personal capacity, while others may act on behalf of agencies or organizations. Powerful stakeholder groups may seek to manipulate the process. Structural issues also affect agendas and outcomes. Open 
structures with loose leadership and membership allow multiple participants to gain access to a fast expanding agenda. Achieving goals in such a wide agenda becomes more difficult as an increasing number of players struggle to resolve differences and coordinate actions.

The stakeholders of collaborative governance in road maintenance assisted by PRIM in NTB Province are relevant local government institutions and the community representatives as follow:

- Road owners.

Road owners are local government - provincial, district and village level. Stakeholder views for this group are obtained at the Governor's office and Bappeda (Regional Development Planning Agency).

- Road users and road use managers

It is a vital stakeholder because each has complementary interests in better road maintenance. Road users consist of individuals and organizations and include public, trade and government users who all need an effective and efficient road network that is able to provide access and connectivity. Communities affected by the road network also have the same concerns regarding maintenance, because of the positive impact of improved access, availability of public transportation and opportunities to earn income. While the negative role is the increased risk of injury or damage, noise, reduced access because the road becomes a barrier and an increasing number of undesirable people, although temporary. Road use managers are agencies that set rules for road use, such as planning and implementing traffic management, road planning in terms of network expansion, and the necessity of road maintenance from the perspective of economic efficiency and law enforcement in the use of roads. This stakeholder group also includes organizations interested in road use management, such as Non-Governmental Organizations (NGOs) and those interested in road maintenance research such as universities.

The views of both road use managers and road users are obtained from the Road Traffic and Transportation Forum (FLLAJ) at the Provincial and District levels. Each of these agencies is tasked with coordinating the interests of civil society with road use planning and maintenance management agencies.

- PPK road maintenance and staff carrying out this service.

PPK is a professional technical division in the Provincial and District Bina Marga, and for selfmanagement (Swakelola) in the provinces there are Balai Lombok and Balai Sumbawa. In each maintenance cycle, the division staff plans, programs, confirms the budget, manages the design and contracts with consultants and contractors for the provision of maintenance services. Since this is a catalyst agency for all technical aspects of road maintenance, input for the technical aspects of road maintenance must be obtained from the agency itself, namely Bina Marga and the DPU PR.

- Road maintenance service providers.

Road maintenance service providers are design and supervision consultants, and contractors appointed by Bina Marga. Because there is no continuity from one maintenance cycle to the next then the views of representatives of industry contractors are collected as information for this study.

- Road regulators.

The Directorate General (DG) of Highways (Bina Marga) is a central level regulation maker for planning all over Indonesia. Under it, Subdirectorate of Subnational roads Technical Guidance (SBTJD) coordinates activities for subnational roads and is therefore the most relevant national stakeholder in maintaining provincial and district roads. This agency clearly has an important role in understanding the maintenance needs of all subnational road networks. Bappenas is the main ministry entrusted with planning the national economy and interested in understanding the impact of improving road maintenance on the national and regional budgets. Likewise, the Ministry of Transportation has issued guidelines on road use management, while the Ministry of Home Affairs has an important role in human resource development, providing funding for staff who will participate in interprovincial training and approval of regional budgets. The view of DG and Head of SBTJD as representatives of the road regulators will be presented in a separate paper. 
Figure 1

Structure of collaborative governance in road maintenance in NTB

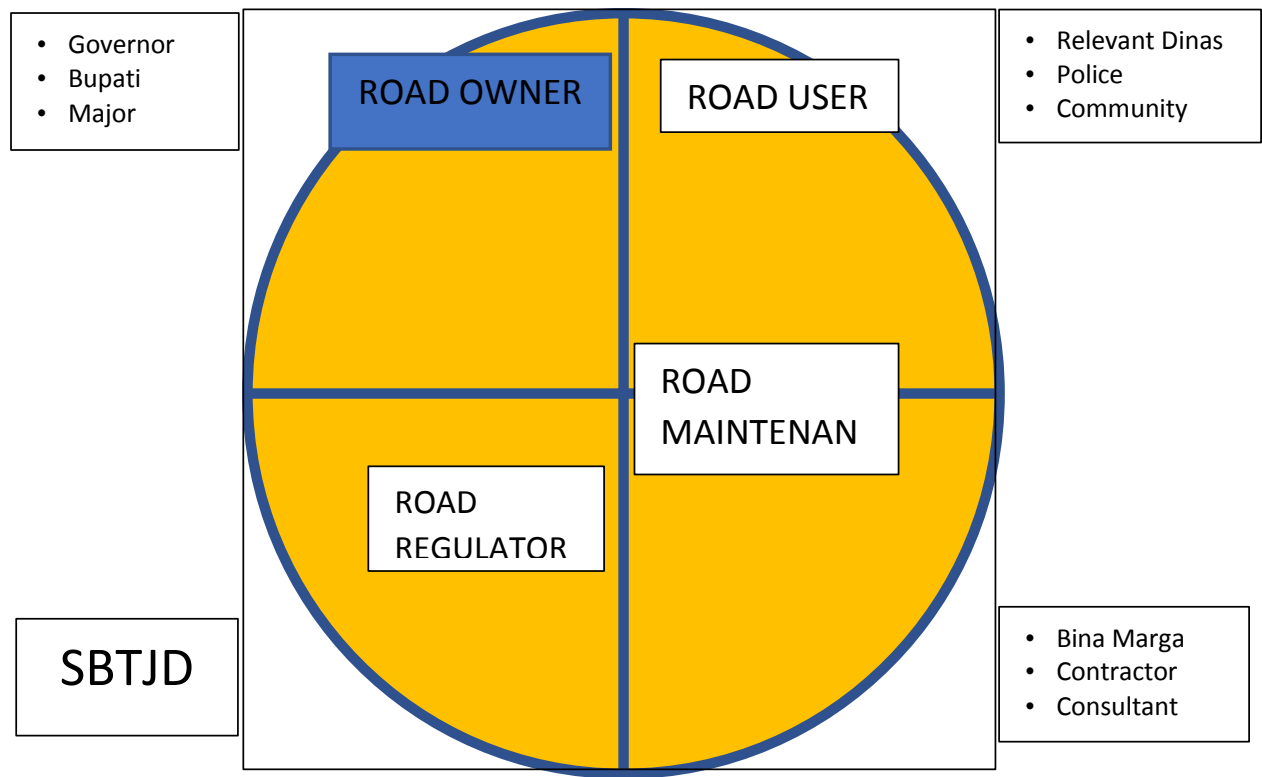


Figure 2.

The Previous Organizational Structure and Function of Bina Marga Division DPU PR Kabupaten Lombok Barat

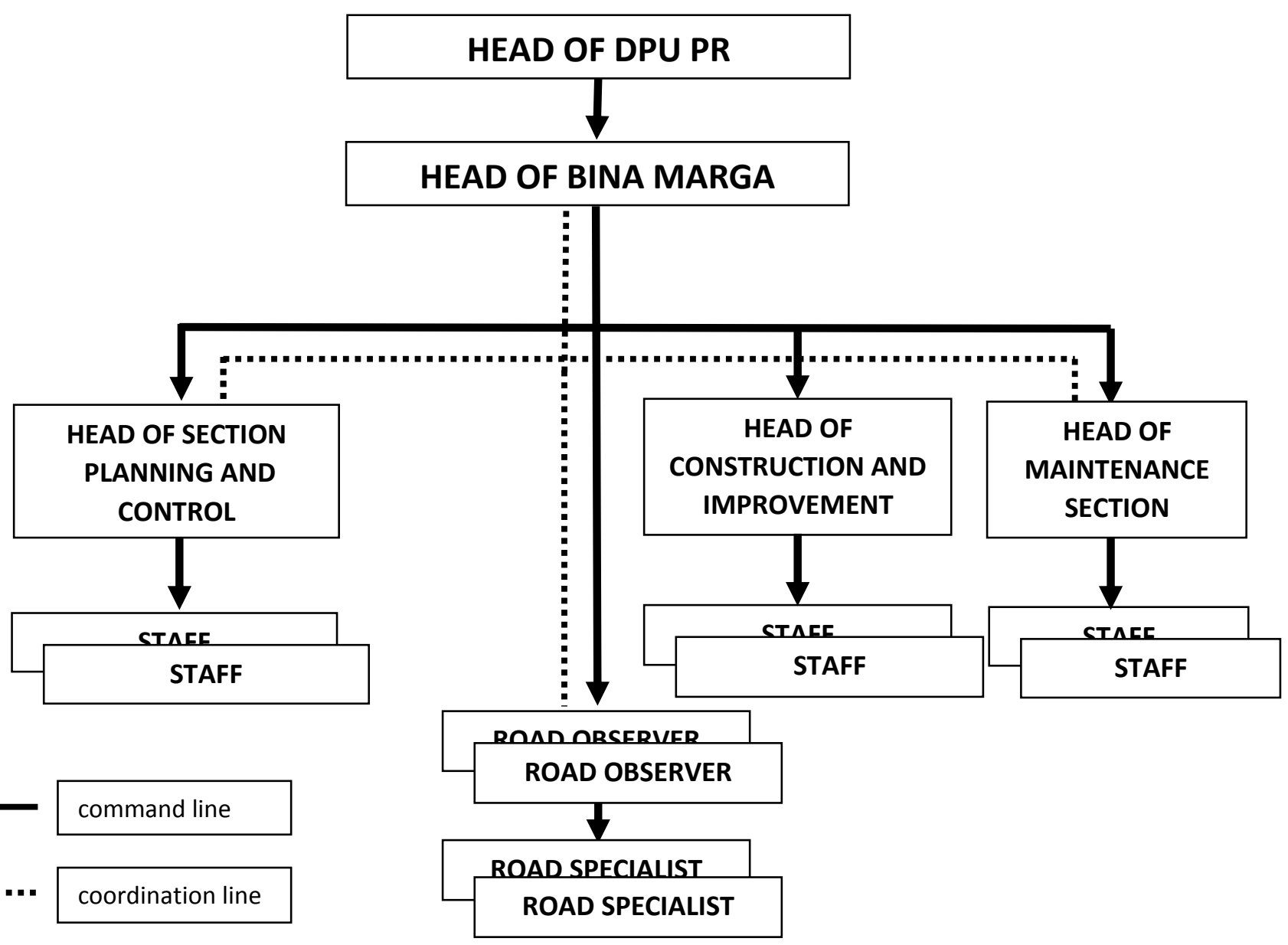


Job description of the human resources of Bina Marga Division before PRIM assistance as follow:

a) Head of Bina Marga Division

Perform planning, development, supervision, control of road and bridge construction management, and utilization of road right of way, and mitigation of natural disaster.

b) Head of Administration and Finance Section and Finance Officer

Assist all organizational units in processing financial administration (revenues and expenditures) and nonfinancial technical administration. Assist in controlling budget and other assignments for expediting cash receipt and expenditures.

c) Head of Planning Section, Road Planner/Surveyor, Budget Planner, and Computer Operator

- Prepare materials for the writing, development, control, monitoring and socialization of technical standardization;

- Prepare materials for road and bridge management and control of utilization of the road's right of way;

- Prepare work plan for road construction implementation.

- Serve as budget reference for program and activity implementation of each unit.

Since the past 5 (five) years as of 2013, the Bina Marga Divisons of the DPU PR of NTB Province and Kabupaten Lombok Barat respectively have received additional human resources functions and support from the PRIM Projects. The human resources function and support include 4 (four) main functions, including: (1) Environmental Management (AMDAL and UKL-UPL); (2) Management of Gender, Social Inclusion (GESI) and Child Protection (CP); (3) Management of Technical and Non-technical Training, and (4) Stakeholder engagement through Road Traffic and Transportation Forum (FLLAJ). The job description and work processes of the 4 (four) additional functions are as follow:

\section{d) Head of GESI and CP Section, GESI and Diffable Officer, and Child Protection Officer}

- Support for FLLAJ Capacity Building

- Develop and strengthen women sub-contractors.

- Support Disability Groups Organizations.

- Women in Engineering.

Work processes:

- Revising FLLAJ membership by including more women and disabled persons as FLLAJ members;

- Design and conduct training on GESI and CP to members of the FLLAJ;

- Recruiting staff of GESI especially for FLLAJ;

- Integrating GESI and Child Protection into the "Road Management Cycle";

- Training on Introduction to Road and Bridge Construction Project Manager for IWAPI members engaged in road and bridge construction services;

- Assisting IWAPI members to prepare the bidding stages, prepare for proposals and project costs and how to bid for road and bridge construction projects;

- Support HWDI (Indonesian Disability Women Association-NTB) to develop institutional capacity of organizations and HWDI members. This is done to encourage members of HWDI able to advocate against the government, especially the policy makers to implement the mandate of Law No. 8/2016, on the fulfillment of the right to protection of disability.

- Supporting HWDI to become a stronger group through HWDI involvement into FLLAJ members so that advocacy can be easier.

e) Head of Training and FLLAJ Section, Training Needs Assessment (TNA) Officer, Training Implementation Officer, and FLLAJ Officer.

Plan training needs, training methods, curriculum and learning methods, facilities and infrastructure, and cooperation with relevant stakeholders, and perform evaluation of training.

- Perform advocacy and support relevant stakeholders in discussing traffic and road transportation issues through FLLAJ by facilitating integration of agencies running traffic and road transportation activities, and prevent disruption to traffic and road transportation that negatively affect social and economic aspects; and/or issues whose settlement requires alignment and interdependency of authority and responsibility of the agencies. 


\section{Work processes:}

- Conduct a study through surveys and/or workshop for relevant stakeholders on training needs;

- Design and prepare TOR of training program packages;

- Design implementation method, curriculum contents, and learning methods in the training;

- Perform cooperation with stakeholders for the training;

- Perform evaluation on training effectiveness.

- Provide advocacy for central and regional government agencies in running traffic and road transportation operators that require integration in traffic and road transportation operations, to be initiators for discussions in the forum;

- Be proactive in proposing for discussion of issues in the traffic and road transportation operation in the forum through central or regional government agencies consistent with the agencies' job description;

- Propose for discussion of traffic and road transportation issues that require integration in traffic and road transportation.

g) Head of Environmental Section and UKL-UPL Officer

- Formulate the steps in preventing, handling and controlling the negative impacts of the road and bridge construction and other affected facilities;

- Formulate steps for improving positive impacts of the construction of the road, bridges and other affected facilities;

- Formulate environmental monitoring steps to identify the effectiveness of environmental management performed for those affected by road and construction construction.

Work processes:

- Prepare guidelines for preventing, dealing and controlling of environmental damage and pollution, which was caused by road and bridge construction and maintenance.

- Prepare guidelines for efforts to minimize the negative impacts and maximize positive impacts caused by the road and bridge construction and maintenance activities;

- Prepare guidelines for environmental management and monitoring;

- Assist in the decision-making process by the government in the environmental management and monitoring as the impacts of road and bridge construction and maintenance.

- Prepare a review to inform the government on compliance in environmental management and monitoring as the impacts of road and bridge construction and maintenance.

The four main functions have given contribution to support the effectiveness and efficiency of subnational road management in NTB Province and Kabupaten Lombok Barat. Therefore, proposed organization structure and function of Bina Marga Division can be seen in Figure 3 below. 
Figure 3.

The Proposed Organizational Structure and Function of Bina Marga Division DPU PR NTB Province and Kabupaten Lombok Barat

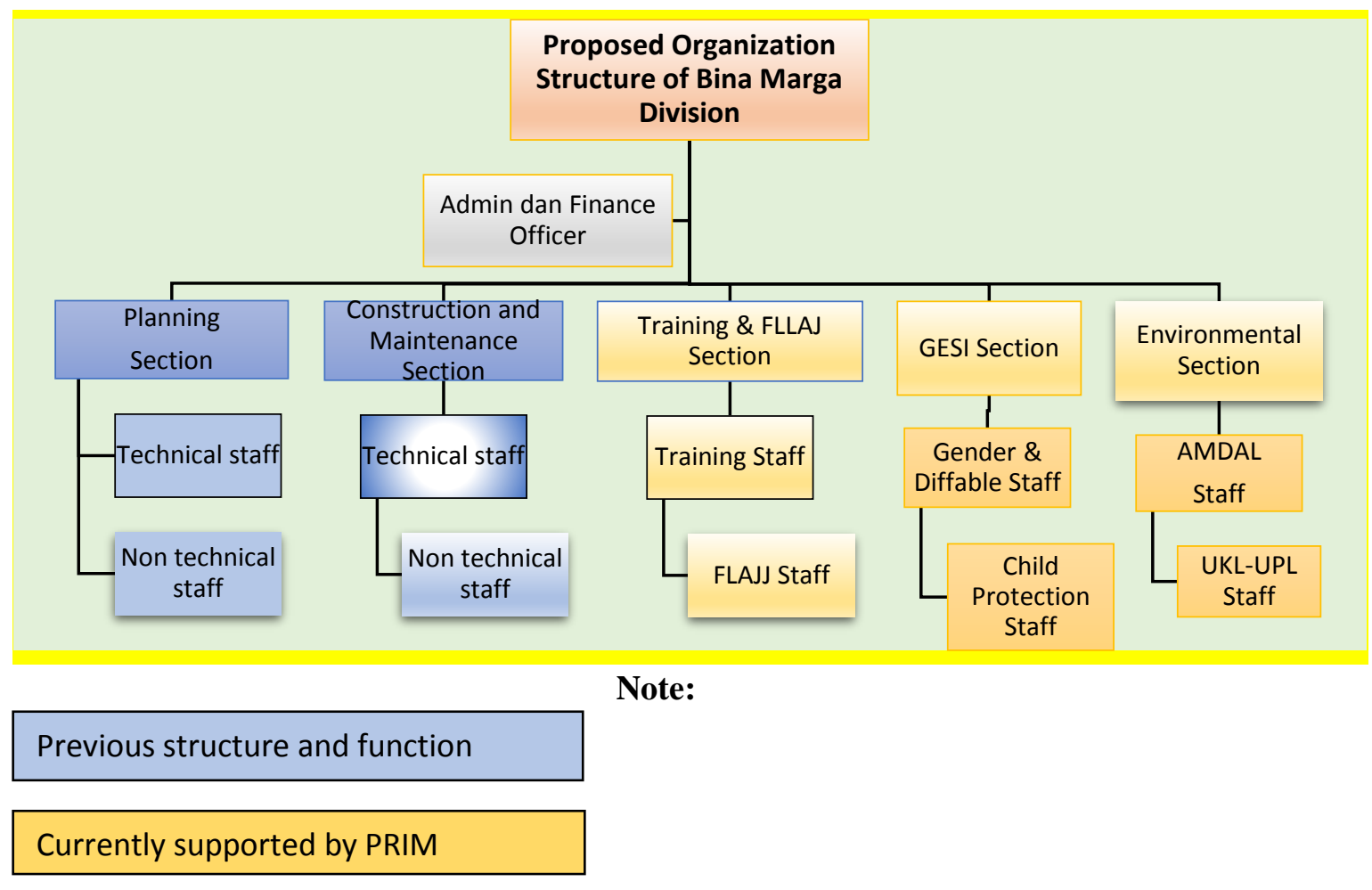

\section{Conclusion and lesson learned}

The advantages of effective collaborative governance are that it enables a better and shared understanding of complex problems involving many stakeholders and allows these stakeholders to work together and agree on solutions. It can help policy makers identify and target problems and deliver action more effectively. the disadvantages of collaborative governance are that the process is time consuming, it may not reach agreement on solutions, and the relevant government agencies may not implement the agreed solutions.

The organization (road user dan road use manager, and PPK) focuses on the task of road maintenance with the leading institutions of Provincial and District level. With the support of the PRIM program, this catalyst organization continues to build capabilities. Now each has the capability to provide referral expertise on certain topics. Their role is the management of road maintenance throughout the maintenance cycle from the initial planning to verification and includes the implementation of maintenance management by contractor consultants and service providers.

In the case of private sector service providers, the lack of exposure to previous associations and even the absence of good institutional memory from members' feedback limits their use as expert resources to answer operational questions regarding design, supervision and contracts. But the commitment of the consultants and contractors to ensure systemic problems in implementation are recognized and handled. There is little evidence that the management of these service providers has absorbed improved skills through PRIM at the management level but does not impose a better culture regarding quality assurance to reduce the lack of responsibility shown by each of them. There is a continuous dependence on supervision by PRIM / Bina Marga, which is increasingly decreasing after the completion of PRIM's assignment. Therefore, the most useful contribution of these service providers is to recognize and further address the two challenges above: the lack of retention of lessons learned through PRIM and the lack of responsibility to deal with their quality assurance issues.

FLLAJ fully has expert resources, access to university staff and the ability to work with communities for consultation. FLLAJ continues to expand its area of influence, for example through a coordinating role for the Construction Sector Transparency (CoST) initiative. FLLAJ continues to strive to improve road safety and plays a very important role in conducting extensive coordination between transportation and roads related to safety 
signs. The risk that might arise is the full sustainability of its activities after the end of PRIM because this requires budget adjustments to replace current benefits received from PRIM incentive funding.

\section{References:}

Abbott, John (2012). Collaborative Governance and Metropolitan Planning in South East Queensland - 1990 to 2010: From a voluntary to a Statutory Model. Australian Centre of Excellence for Local Government (ACELG), Sydney.

Ansell, Chris \&, Alison Gash (2008). "'Collaborative Governance in Theory and Practice' Journal of Public Administration Research and Theory, 18(4): 543-571" (PDF).

Emerson, Kirk, Tina Nabatchi, Stephen Balogh (2012). "An Integrative Framework for Collaborative Governance". Journal of Public Administration Research and Theory. 22 (1): 1-29.

PRIM-PIUC, Studi Kelayakan Pusat Rujukan Nasional untuk Program Peningkatan Kinerja dan Pemeliharaan Jalan Provinsi, AECOM and KIAT, October 2017.

PRIM-PIUC, Human Resources Competency Planning and Development Bina Marga Division of DPU PR NTB Province and Kabupaten Lombok Barat, Consultant Report to AECOM and KIAT, July 2018.

PRIM-PIUC, PRIM: Vision, Mission, Purpose, and Values 